\title{
Tokiko Garapen Agentzien eta Ekonomia Sozial eta Solidarioaren gaitasuna Tokiko Giza Garapenaren bidean: Agència de Desenvolupament del Bergueda-ren esperientzia aztergai ${ }^{1}$
}

\author{
Andoni Zulaika Arriaga \\ Técnico de Empleo Social (Beterri-Buruntza Udalak) \\ anlozulaika@hotmail.com
}

DOI: $10.1387 /$ reves.19509

Sarrera data: $2017 / 03 / 24$

Onarpen data: 2017/05/02

Aurkibidea: 1. Sarrera. 2. Tokiko Giza Garapena eta Ekonomia Sozial eta Solidarioa. 2.1. Tokiko Giza Garapena: Tokiko dimentsioa eta gaitasunen ikuspegia. 2.2. Gaitasun zentral eta kolektiboak eta Ekonomia Sozial eta Solidarioa. 3. Kasuko azterketa: Agència de Desenvolupament del Bergueda. 3.1. Azalpen metodologikoa. 3.2. Analisi subjektiboaren emaitzak. 4. Ondorio nagusiak. 5. Bibliografia.

\section{Laburpena:}

Artikulu honetan azalduko dugun ikerketak gaur egungo ekonomia eta garapen eredua zalantzan jarri eta norbanako guztien ongizatea bermatuko duen ekonomia eta garapen eredu berritu baterako gakoak ematea bilatzen du.

Ikerketaren hipotesi nagusia hiru zutaberen gainean garatu da: Tokiko Giza Garapena, Ekonomia Sozial eta Solidarioa eta Tokiko Garapen Agentziak. Tokiko Giza Garapena sustatzeko Ekonomia Sozial eta Solidarioak, euskarri gisa, eta paradigma ekonomiko hau oinarri duten Tokiko Garapen Agentziak, tresna instituzional gisa, duten gaitasuna defendatu nahi izan da, bai modu teoriko nahiz enpirikoan.

\section{Hitz gakoak:}

Ekonomia Sozial eta Solidarioa, Tokiko Garapen Agentziak, Tokiko Giza Garapena, Gaitasunen ikuspegia, Tokiko dimentsioa.

1 Artikulu hau, 2016an UPV/EHUko Ekonomia Sozial eta Solidarioa Unibertsitate Masterrean aurkeztutako hurrengo master amaierako lanean oinarritua dago: «Tokiko Garapen Agentziak eta Ekonomia Sozial eta Solidarioa: Tokiko Giza Garapenerako tresna eta euskarri». 


\title{
Resumen:
}

El artículo que tenéis entre manos, parte del cuestionamiento del actual modelo económico y de desarrollo, y se centra en dar las claves para un nuevo modelo económico y de desarrollo que garantice el bienestar de todos los individuos.

La hipótesis principal de la investigación se desarrolla en base a tres pilares fundamentales: Desarrollo Humano Local, Economía Social y Solidaria y Agencias de Desarrollo Local. Esta hipótesis defiende, de una forma tanto teórica como empírica, la capacidad de la Economía Social y Solidaria, como soporte económico, y las Agencias de Desarrollo que incorporan este paradigma económico, como herramientas institucionales, de cara a promover el Desarrollo Humano Local.

\section{Palabras clave:}

Economía Social y Solidaria, Agencias de Desarrollo Local, Desarrollo Humano Local, Enfoque de capacidades, Dimensión local.

\begin{abstract}
:
The intention of this research project is to question nowadays economic and development model and to identify the key characteristics of a new model that will guarantee the social welfare of every individual.

The main hypothesis of this research is based on three main blocks: Local Human Development, Social and Solidary Economy and Local Development Agencies. In this manuscript, we endorse the idea that Local Development Agencies —taken as institutional instruments - that part from a Social and Solidary Economy paradigm have the capacity to potentiate Local Human Development. Both in theoretical and empirical way.
\end{abstract}

\section{Keywords:}

Social and Solidary Economy, Local Development Agencies, Local Human Development, Capacities view, Local dimension

\section{Claves Econlit:}

O150, P480, R110, R580.

\section{Sarrera}

Artikulu honetan azaltzen den ikerketak gaur egungo ekonomia eta garapen eredua zalantzan jarri eta norbanako guztien ongizatea bermatuko duen ekonomia eta garapen eredu berritu baterako gakoak ematea bilatzen du. 
Ikerketaren hipotesi nagusia hiru zutaberen gainean garatu da: Tokiko Giza Garapena, Ekonomia Sozial eta Solidarioa eta Tokiko Garapen Agentziak. Tokiko Giza Garapena sustatzeko Ekonomia Sozial eta Solidarioak, euskarri gisa, eta paradigma ekonomiko hau oinarri duten Tokiko Garapen Agentziak, tresna instituzional gisa, duten gaitasuna defendatu nahi izan da, bai modu teoriko nahiz enpirikoan.

Artikuluaren lehen atalean ikerketaren marko teorikoa garatzen da. Alde batetik, egungo ekonomia eta garapen eredua zalantzan jarri eta hazkunde ekonomikotik haratago doan garapen eredu berritu baten - Tokiko Giza Garapena- proposamen teorikoa azaltzen da, aldi berean, Ekonomia Sozial eta Solidarioa oinarri duten Tokiko Garapen Agentziak tresna instituzional gisa proposatuz. Beste aldetik, Ekonomia Sozial eta Solidarioak, gaitasunen ikuspegiarekin duen lotura aztertu eta paradigma ekonomiko honek gaitasun pertsonal eta kolektiboak sustatzeko duen potentzialitatea azalduko da. Jarraian, marko teorikoan planteatutako hipotesi teorikoak baieztatze aldera, Agència de Desenvolupament del Bergueda-k garatutako Ekonomia Sozial eta Solidarioko egitasmo ezberdinen gaineko kasuko azterketaren emaitzak azalduko dira. Bukatzeko, ikerketaren ondorio nagusiak laburbilduz itxiko da artikulua.

\section{Tokiko Giza Garapena eta Ekonomia Sozial eta Solidarioa}

Ekonomia konbentzionalak — globalizazio neoliberala - eta bere pentsamendu dominatzaile hegemonikoak finkatzen ditu modu sistematikoan gaur eguneko merkatuko printzipio eta joko arauak. Hau da, eredu ekonomiko honek du gaur eguneko sistema sozioekonomikoan botere araugilea, berak finkatzen ditu gizabanako, talde, komunitate eta herrialdeen arteko truke prozesu guztiak antolatzeko oinarrizko printzipio edota arauak. Logika utilitarista bati jarraitzen dio gainera eta ondorioz denak du truke-balioa, dena da merkantzia, gizakia eta giza gaitasunak, natura, ezagutza eta baita giza harremanak (afektua, zaintza edota kultura) ere (Guridi eta Perez de Mendiguren, 2014).

Eta nola ez, egungo Tokiko Garapen eredua ere, ekonomia kapitalistaren logika, printzipio eta arauen baitan dago eraikia. Tokiko Garapenaren ikuspegi konbentzionalak, garapenaren dimentsio anitzak barneratzen baditu ere, oinarri material produktiboan zentratzen da eta garapen ekonomikoa du ardatz. Defendatzen den hipotesi nagusia, hazkunde ekonomikoak modu zuzenean garapena sortzen duela da eta honek batera etorriko dela ongizatea gizartean.

XIX. mende bukaeratik, hainbat ikuspuntu edo korronte egon dira kapitalismoa eredu gisa zalantzan jarri dutenak edota bere aurkako joera na- 
barmen adierazi dutenak, euren artean Ekonomia Sozial eta Solidarioa. Proposamen alternatibo hau, XIx. mende amaierako korronte ideologiko ezberdinetan — sozial-kristau, sozialista eta anarkista- du jatorria eta xx. mendean zehar garatutako korronte ekonomiko kritiko ezberdinetatik —ekonomia feminista, ekonomia komunitarioa, etab. - elikatu da $(\mathrm{Gu}-$ ridi eta Perez de Mendiguren, 2014).

Ekonomia ereduaren gaineko eztabaida honetan, garapen ereduaren gaineko eztabaida ere hor egon da, dena baitago elkarlotua, eta xx. mendearen azken hamarkadatik hona gorpuzten joan den Tokiko Giza Garapenaren proposamen teorikoa da hurrengo puntuan azalduko duguna.

\subsection{Tokiko Giza Garapena: Tokiko dimentsioa eta gaitasunen ikuspegia}

Gaur egun, Tokiko Giza Garapenaren gaineko hainbat ikuspegi eta proposamen badaude ere, ekonomia kapitalistaren logika globalizatzailearekin mozten duten ikuspegi kritikoak hartu nahi izan ditugu oinarri gure proposamen teorikoa gorpuzteko.

Duboisen (2014) ustez, bi dira garapen eredu konbentzionalarekin krititiko diren ikuspegi ezberdinek elkarbanatzen dituzten premisak. Batetik, ikuspegi integralaren beharra. Ekonomia tradizionalak proposatzen duen ikuspegi ekonomikotik haragoko dimentsioak (soziala, politikoa, kulturala, ekologikoa...) kontuan hartzearen beharra eta garrantzia; garapen ekonomikotik haratago doan eredu bat. Beste aldetik, garapen endogenoaren premisa, tokian tokiko agente eta baliabideei ematea zentralitatea eta beraien esku ustea beraien esparru geografikoaren garapena (Dubois, 2014).

Tokiko Giza Garapenaren proposamen honek, bi premisa hauek bere osotasunean betetzen ditu eta hurrengo bi erreferentzia teoriko nagusitan du oinarria: Tokiko dimentsioa eta gaitasunen ikuspegia. Tokiko dimentsioak, territorialitatearen garrantzia nabarmentzen du, hau da, garapen estrategia aurrera eramango duen subjektuaren eta espazioaren definizioan. Gaitasunen ikuspegiak ordea, giza garapena garapenaren zentroan jartzea defendatzen du. Hau da, Tokiko Giza Garapenak pertsonen garapena izan behar duela helburu eta ez gizakiak medio gisa erabili ustezko garapera lortzeko.

Tokiko Giza Garapena beraz, tokiko dimentsioa - territorioa eta garapen endogenoa - eta gaitasunen ikuspegia — giza garapena — oinarri dituen garapen eredua da.

\subsubsection{Tokiko dimentsion eta Tokiko Garapen Agentziak}

Tokiko dimentsioak, subsidiariotasun printzipioa du oinarri, hau da, tokian tokiko problematika konkretuei erantzuteko, hurbileneko gober- 
nantza maila dela eraginkorrena. Hala ere, honek ez du esan nahi arazo guztien erantzunak maila geografiko hurbilenean emango direnik egokien, baina bai erantzuna emateko eskumenaren preferentzia maila hurbilenekoak izan behar duela (Kazepov, 2010).

Gobernantza ereduaren gaineko eztabaida sartzen da hemen. Gobernantza maila desberdinen - lokal, probintzial, nazional, kontinental eta mundiala - funtzioak eta erregulazio ahalmenak etengabe joan dira aldatzen eta berrantolatzen kapitalismoaren akumulazio fase ezberdinetan.

Estatua izan da historikoki prozesu ekonomiko eta sozialen definiziorako limite territorial garrantzitsuena. Azken hamarkadetan ordea, paktu keynesiar sozialdemokrata apurtu zenetik, ekonomiaren globalizazio prozesu azkarra bizi izan dugu eta prozesu ekonomikoak eta sozialak erregulatzeko eskumena ere globalizatu egin da. Enpresa multinazionalen boterearen hazkuntzak eta gobernantza globalerako Bretton Woodsetik irtendako nazioz gaindiko instituzioek enpresa hauen boterea geldiarazteko izan duten ahultasunak ekarri gaitu egungo egiturazko krisian murgiltzera. Ondorio sozial, ekologiko eta ekonomiko nabariak pairatu dira alor sozioekonomikoan egondako erregulazioaren garapen ahularen eta politika ekonomikoen gabeziaren ondorioz. Nazioarteko kapital handien mugimenduek, produktu kate globalek eta lan merkatu globalizatuak, beste hainbat arrazoiren artean, enpresa trasnazionalei izugarrizko boterea eman die eta nahiz eta erregulazioak estatalak izan, enpresa hauek aukera izan dute nahi duten erregulazioa aukeratzeko.

Joera globalizatzaileak duen indarra ikusirik, beharrezkoa dela uste dugu espazio lokalen - tokikoa - eta gobernantza lokalaren berrindartze bat bultzatzea. Aldi berean, garapen estrategia tokiko agente ezberdinek diseinatutako proiektu politiko komunitario konplexu eta anitza izan behar duela uste dugu.

Tokiko dimentsioaz hitz egitean beraz auzo, herri, hiri edota eskualdeetako maila territorialaz ari gara, ez maila probintzial edo nazionalaz. Garapen endogenoa oinarri, Tokiko esparrua - territorioa - izan beharko da garapen estrategia garatzeko espazioa edo markoa eta tokian tokiko norbanako eta agenteak —ekonomikoak, sozialak, instituzionalak eta politikoak - izango dira territorioan ongizate pertsonal eta kolektiboa lortzen lagunduko dien garapen eredua eta garapen estrategia definituko dutenak.

Endogenotasuna ordea, ezin da modu hermetiko batean ulertu. Jakina da ekonomia globalaren joerak eta gobernantza lokalaren goitik dauden instituzioen -maila probintzial, nazional, kontinental, mundiala - erabakiek nabarmen mugatzen eta eragiten dutela Tokiko Giza Garapeneko estrategiaren diseinuan eta eboluzioan. Horregatik, ezinbestekoa izango da lurraldea gobernantza maila ezberdinekin eta lurraldetik kanpo dauden 
agente politiko, sozial eta ekonomikoekin harremantzea. Beti ere, kontuan hartuz goragoko gobernantza mailek sortzen duten baldintzapena, hala ere, gakoa baldintzapenaren eta subsidiariotasun printzipioaren arteko etengabeko harreman dialektikoan egongo da. Helburua talka honetan, Tokiko Giza Garapenarentzat goragoko gobernantza mailen baldintzapena murriztu eta subsidiariotasun printzipioa gailentzea izanik (Dubois, 2014).

Tokian tokiko estrategia sustatzeko tresna instituzionala zein definitzea falta da oraindik. Gure inguruabarrean garapen estrategia aurrera eramateko espazioa eskualdea izanik eta subsidiariotasun premisa kontuan hartuz, Tokiko Garapen Agentziak gobernantza lokaleko tresna instituzional eraginkorrak izan daitezkeela uste dugu. Tokiko Garapen Agentziak gobernantza lokalaren garapen instituzionalaren emaitza dira eta Espainiar estatuan koiuntura konkretu batean jaiotzen dira, botere politikoa «goitik behera» - probintzia, eskualde eta udaletxeak - eta «behetik gora» -instituzio europarren sorrera- birbanatzen den momentuan bereziki. Arrazoi hauengatik, tresna instituzional hau hartuko dugu, Tokiko Giza Garapeneko estrategia sustatzeko agentetzat.

\subsubsection{Gaitasunen IKUSPEgia}

\section{a) Gaitasunen ikuspegiaren bilakaera}

Tokiko Giza Garapenaren proposamena osatzen jarraitzeko, tokiko dimentsioari gaitasunen ikuspegia gehitu behar zaio. Gaitasunen ikuspegiak, giza garapena jartzen du zentroan. Garapen estrategiaren helburua pertsonen garapena eta ongizatea izan behar dira eta ez gizakiok hazkunde ekonomikoaren bitarteko gisa erabili ustezko garapena.

Aurrera jarraitu aurretik, argipen bat: Giza garapena eta gaitasunen ikuspegia sinonimo bezala erabili izan dira maiz, baina ez dira gauza bera. Giza garapena, gaitasunen ikuspegia barneratzen duen garapen eredu proposamen bat da, eta nahiz eta ikuspegi hau zentrala izan garapen ereduan, beste hainbat ekarpen teorikotatik ere elikatzen da (Dubois, 2008). Giza garapena definizioz, gizakien bizi kalitatea eta oinarrizko justizia soziala neurtzen dituen garapen eredua da (Jubeto eta Larrañaga, 2013).

Amartya Sen (1990) da ikuspegi honen aitzindaria eta 1990ean proposatutako gaitasunen ikuspegiak PNUDek* bultzatutako giza garapenaren oinarri teorikoa finkatu zuen. Hala ere, 1990ean Giza Garapenaren lehen informea atera zenetik, giza garapenaren gainean asko idatzi da eta aurrerapen asko egin dira maila teoriko eta politikoan. Azken urteetan Mahbub ul Haq, Amartya Sen eta Martha Nussbaum izan dira, besteak beste, kontzeptu honen teorizazioaren oinarriak definitu dituztenak (Jubeto eta La- 
rrañaga, 2013). Garrantzitsua da ikuspegiaren bilakaera ondo azaltzea teoria ondo ulertu ahal izateko.

Gaitasunak, edo funtsezko askatasunak ${ }^{2}$ —Senek (1990) definitzen dituen moduan-, elkar harremanetan dauden aukeren multzo bat dira eta zuzenean lotuak daude eskubideen ikuspegiarekin — pertsona bakoitzak zer nolako bizitza izan nahi duen aukeratzeko eskubidea du-. Aukeren multzo hau izateko, beharrezkoa da pertsonen gaitasunak garatzea, horrela, pertsona bakoitzak bere bizi ikuskera pertsonaletik bere bizitza antolatzeko gaitasuna edo askatasuna izan dezan (Nussbaum, 2012; Nussbaum, 2002).

Orokorrean, oinarrizko gaitasun gisa hartzen direnak — bizi luze eta osasuntsua bat bizitzea, kalitatezko hezkuntzara sarrera, komunitatean parte hartzeko errekurtsoak izatea etab. - oso garrantzitsuak dira, izan ere, gaitasun hauek gabe aurretik aipatutako aukeren multzoa nabarmen mugatzen da. Hala ere, giza garapena gaitasun hauetatik haratago doa eta bizitza kalitatea bermatzeko beste esfera batzuk ere hartzen ditu kontuan. Giza-eskubideak, giza segurtasuna, bizitzaren eta planetaren zaintza - beste batzuen artean - funtsezko bermeak izan behar dira pertsona oso bat eraikitzeko komunitate baten barnean. Giza garapena beraz, gizakien, gizakientzako eta gizakiarentzako garapena da (Jubeto eta Larrańaga, 2013).

Pertsona oso bat eraikitzeko beharrezko gaitasunak garatze aldera, Senek gizakiaren «agentzia» ${ }^{3}$ terminoa erabiltzen du, gaitasunen ikuspegia dago zentroan eta askatasunarekin lotzen du zuzenean. Kontzeptu hau, oso lotua dago Hegoaldeko mugimendu feministetatik proposatzen eta bultzatzen duten ahalduntze estrategiarekin (estrategia de empoderamiento). Ahalduntze estrategiak, genero asimetria indartzen eta birproduzitzen duten botere egitura - legeak, jabetza eskubidea eta instituzioak - oro eraldatu nahi du.

Genero ikuspegia funtsezkoa da gaitasunen ikuspegia lantzerako orduan, bi arrazoirengatik. Alde batetik, zalantza ezina da genero asimetriak duen garrantzia, ezin da ukatu hainbat eremu geografikotan konkretuki, eta baita mundu osoan ere, desoreka eta zapalkuntza nabarmen bat dagoela. Gainera genero asimetriaren asimilazio honek arazo bat suposatzen

${ }^{2}$ Funtsezko askatasunak: «Askatasun instrumentala» (Libertades instrumentales) bezala ere definitzen ditu Senek. Funtsezko askatasun hauek, gaitasun zentralak indartzen laguntzen dute eta politika publikoen bitartez sustatu daitezke. Bost askatasun mota definitzen ditu: a) Askatasun politikoa, b) Erraztasun ekonomikoak, c) Aukera sozialak, d) Gardentasun bermea, e) Segurtasun sarea.

3 Agentzia: norbanakoek beraien helburu edo baloreak modu aske eta autonomo batean lortzeko duten ahalmena da. (Sen, 1985) 
du garapen klabetan, izan ere, emakumeei aukerak sistematikoki ukatzeak herrialde askoren garapena oztopatzen du. Beste aldetik, genero ikuspegiak gaur egungo garapenaren ikuspegi konbentzionalaren gabeziak nabarian usteko balio duelako eta gaitasunen ikuspegiaren egokitasuna baieztatzen laguntzen duelako (Nussbaum, 2012).

Hainbat izan dira gaitasunen ikuspegiaren gainean egindako ekarpenak, baina baita izandako eztabaidak ere. Eztabaida korapilatsuenetako bat ongizatearen dimentsio kolektiboaren gainekoa izan da.

PNUDek, oraindik, giza garapenaz hitz egitean Senen gaitasunen ikuspegi zaharkitua hartzen du erreferentzia gisa eta hainbat autorek Senen gaitasunen ikuspegi hau kritikatu izan dute,bereziki, ez duelako ongizatearen dimentsio kolektiboa bezain beste kontuan hartzen edo ez duelako egoki lantzen. Senek, pertsonaren gaitasunen sustapenean jartzen du enfasia ongizatea lortzera bidean eta dimentsio pertsonala kolektiboaren gainetik jartzea kritikatzen diote. Sen gaitasunen ikuspegiaren aitzindaria izan arren, hasierako proposamenaren izaera indibidualista da zalantzatan jarri dena azken urteetan (Dubois, 2008).

Robeynsek, Senen hasierako proposamenaren etika indibidualistari buelta emateko, dimentsio kolektiboa aztertzeko marko analitiko berriak sortzea proposatzen du (Robeyns, 2005). Robeynsek proposamenari jarraiki, hainbat autorek - Nelson (2004), Gasper y van Staveren (2003) eta Nussbaum (2002 eta 2003) — dimentsio kolektiboaren gaineko proposamenak egin dituzte. Autore hauek hainbat puntutan desadostasunak izan arren, denek kritikatzen dute Senen "funtsezko askatasunen» proposamena -bakoitzak bere ustez duina den bizitza bat bizitzeko gaitasuna-. Askatasunaren kontzientzia, norbanako bakar gisa dugun kontzientzia da eta ikuskera honek desberdintasunen aferan arrisku nabarmenak sor ditzake. Izan ere, non hasi eta bukatzen da bataren eta bestearen askatasuna. Adibide argiena emakumeena edo ingurumenarena da, biak ala biak egunero erasotuak askatasunaren izenean.

Nelsonek (2004) askatasunaren kontzepzioak giza nortasunaren (condición humana) funtsezko gaitasun bat aipatzen du, afiliazioa - hau gabe ezin da ulertu askatasuna-. Afiliazioak, norbanako bakoitzak beste gizakiekin eta orokorrean mundu sozialarekin erlazionatzeko duen kontzientzia definitzen du eta ekonomia feministan askotan aipatu izan den gizakien arteko interdependentzia kontzeptua barneratzen du.

Nussbaum (2003) pausu bat haratago joaten da, justizia soziala eta genero arteko justizia (justicia de genero) helburu izango dituen ongizatea definitzearen beharra ikusten du. Senek justizia sozialarekiko duen konpromisoa aipatzen du, hala ere, bere proposamenari justizia soziala lortzera bidean berdintasuna helburu politiko gisa jartzea eta gaitasunen arteko berdintasuna bilatzea falta zaizkiola nabarmentzen du. Gai- 
nera, Desarrollo y libertad (2000) lanaren gainean, aurretik aipatu ditugun kritikak bere egiten ditu eta zein askatasun ez diren egokiak edo onak - justizia sozialaren aurka doazenak - definitzea falta dela gehitzen du. Ildo honetan, justizia lege bat definitu behar dela dio, eta ez soilik gizarte bakoitzean, baita munduko herrialde desberdinetako egoera eta praktikak ebaluatu eta alderatzeko ere. Era honetara, errazagoa izango da garatu beharreko gaitasunak sustatzeko politika publikoak diseinatu eta praktikara eramatea. Bere ustez, justizia legeak erreferente gisa balio dezake justizia soziala eta ongizatea lortzera bidean. Garapenak azken finean, norbanako guztiek bizitza duin bat izateko aukera eta baldintzak eskaini behar ditu (Dubois, 2008).

Gaitasunen ikuspegia etengabeko eztabaidan dagoen ikuspegi bat dela argi geratu da. Hala ere, gauzatu dugun ikerketan Ekonomia Sozial eta Solidarioak norbanakoen gaitasunen sustapenean duen ahalmena neurtzeko, autore ezberdinen bi gaitasunen zerrenda itxi aukeratu ditugu: gaitasun zentralen zerrenda eta gaitasun kolektiboen zerrenda.

\section{b) Gaitasun zentral edo pertsonalak}

Nussbaumek (2002) kulturaz gaindiko gaitasun pertsonal edo zentralen zerrenda itxi bat definitzea posible dela uste izan du, hala ere, lantzeko zegoen zerrenda bat proposatu zuen 2002an. 2011an, Robynsenek, Nussbmaumen proposamena oinarri hartuz, gaitasunen zerrenda berritsuago bat proposatu zuen, gaur eguneko herrialde garatuen errealitatera egokituz. Bi zerrendak bizitza duin baterako gakoak kategorizatzen saiatzen dira eta bi kasuetan gaitasun zentral guztiak elkar-harremanetan daude.

Nussbaumek gorputzaren eta buruaren osasuna, osotasun fisikoa, zentzumenak, emozioak... bezalako gaitasunak nabarmentzen ditu, baina aldi berean, erlazioei ere garrantzi esanguratsua ematen die, bai pertsonen artekoari eta baita espezien artekoari ere (zentzumenak, emozioak, afiliazioa, beste espezieak, ingurumenaren gaineko kontrola). Robeynsek lanerako - lan produktibo ordaindua zein lan erreproduktibo ez ordaindua - sarbideari ematen dio garrantzia nabarmena, zaintza lanen ikusezintasuna eta ordainketa eta balorazio eza mahai gainean jarriz. Honekin batera, denboraren erabileraren gainean erabakitzeko boterea gehitzen du gako gisa eta Nussbaumek proposatzen dituen kategoria batzuk ere desglosatzen ditu (Jubeto eta Larrañaga, 2013). Esan bezala, Robeynsenen (2011) zerrenda hartuko dugu ikerketarako euskarri eta autore honek hurrengo gaitasun zentral edo pertsonalak zerrendatzen ditu: 


\section{1.taula}

Lan honetarako egina, Robeyns (2011) oinarri hartuta

Ingrid Robeynsen gaitasu zentralak

1. Bizitza eta osasun fisikoa: Osasun fisikoa izan eta iraupen normaleko bizitzaz gozatzeko gaitasuna.

2. Ongizatea eta osasun mentala: Ongizatea bermatuko dizun osasun mentala edukitzeko gaitasuna.

3. Osotasun eta segurtasun fisikoa: Edozein eraso edo aginduren aurrean babestu eta seguru bizi ahal izatea.

4. Harreman sozialak: Sare sozialen baten parte izan eta sostengu soziala eman eta hartzeko gaitasuna.

5. Ahalduntze politikoa: Erabakigune politikoetan parte hartu eta eragiteko gaitasuna izatea.

6. Hezkuntza eta jakintza: ikasteko, ikasitako irakatsi eta ikasitakoaren bitartez jakintza sortu ahal izateko gaitasuna.

7. Etxeko lana eta zaintza lan ez ordaindua: umeak hezi, etxeko lanak egin eta ingurukoak zaintzeko gaitasuna.

8. Lan ordaindua (enplegua) eta beste proiektuak: Lan merkatuan edota bestelako proiektu ekintzaileetan —artistikoak edo kulturalak esaterako- lan egiteko gai izatea.

9. Etxebizitza eta ingurumena: Ingurune seguru eta egoki batean seguru bizi ahal izateko gaitasuna.

10. Mugikortasuna: mugikortasun askatasuna izatea.

11. Aisialdi ekimenak: Aisialdi ekimenetan parte hartzeko aukera izatea.

12. Denboraren erabileraren gaineko erabakitze ahalmena

13. Errespetua: errespetuz eta duintasunez tratatua izateko eta tratatzeko gaitasuna.

14. Erlijioa: erlijio bat aukeratu eta izateko edo ez izateko askatasuna.

d) Gaitasun kolektiboak

Ikuspegiaren etika indibidualistaren kritika gure eginez, garapenaren dimentsio kolektibori eman beharreko zentralitatea eman diogu. Dimentsio kolektiboaz hitz egiten dugunean, ongizatearen taldeko dimentsioaz ari gara eta hau lortzeko jarraitu beharreko prozesu kolektiboaz, gaitasunak garatzeko $^{4}$ — gaitasun indibidual eta kolektiboetatik haratago, gizarte osoaren gaitasuna barneratzen $\mathrm{du}$ - prozesua. Nussbaumen arabera, ongizatearen lorpenerako prozesu kolektiboen baitan gaitasun zentralen garapena ezin dugu prozesu kolektibo bezala ulertu, izan ere, gaitasun hauek norba-

${ }^{4}$ Gaitasunen garapena (capacity development): gaitasun oro hobetzeko, osatzeko eta garatzeko prozesua da. Trebetasunen eta gaitasunen arteko lotura egin behar da gaitasunak sustatzeko eta indartzeko (Baser eta Morgan, 2008). 
nako bakoitzaren eta hurbileneko taldeen (familia, komunitatea...) arteko harremantzeari egiten diete erreferentzia. Aipatu beharra dago, gaitasunen ikuspegiak, pertsonaren kontzepzioa politikoa hartzen duela kontuan, eta pertsona animali sozial eta politiko bezala kontsideratzen duela. Hau da, etengabeko harremanean dagoen norbanako gisa hartzen du eta beste norbanakoekin helburu sozial bateratuak ditu. Ongizate pertsonala beraz, ezin dugu gaitasun zentraletara mugatu eta prozesu zabalago batean barnean kokatu behar dugu, ongizatea lortzeko dimentsio kolektiboko prozesuaren barnean kokatu behar dugu (Nussbaum, 2007:166).

Gaitasunak garatzeko eta ongizate soziala lortzeko prozesu kolektibo honetan, Baser eta Morganek (2008) gaitasun kolektiboen zerrenda bat proposatzen dute eta horrela definitzen dituzte gaitasun kolektiboak: talde edo erakunde batek egunez egun gauzak egiteko eta mantentzeko duen tre-

\section{2.taula}

Lan honetarako egina, Baser eta Morgan (2008) oinarri hartuta

\section{Baser eta Morganen gaitasun kolektiboak}

1. Konpromisoa eta erakarpena: Jarduera desberdinen garapenean parte hartu eta konprometitzeko gaitasuna; baita, talde edo erakunde ezberdinek jarduerak eta espazioak sortu eta sustatzeko duten gaitasuna ere — konpromisoa, ausardia eta identitate kolektiboa oinarri- .

2. Zeregin edo funtzio logistikoak betetzea, zerbitzuak eta teknikak eskaintzea: Komunitatearen garapenaren bidean, erakundeek, dituzten dinamizazio zeregin logistikoak betetzeko borondatea izatea eta beharrezkoak diren zerbitzu eta teknikak eskaintzeko gaitasuna izatea.

3. Harremanak edukitzea eta laguntzak eta baliabideak lortzea: Funtsezkoa da testuinguru bakoitzeko beste eragileekin harremanak edukitzea eta mantentzea, bizirik irauteko eta garapenerako beharrezkoa diren laguntza eta baliabideak lortzeko.

4. Egokitzea eta berritzea: Testuinguruaren aldaketei aurre egiteko edo era egoki batean erantzuteko beharrezkoa den gaitasuna da. Gaitasun hau, zuzenki lotua dago taldearen — eta bertako norbanakoen - ikasteko ahalmenarekin, barne hausnarketak izateko gaitasunarekin, erakundearen berreraberritze ahalmenarekin, edota ideia berriak sortzeko gaitasunarekin.

5. Koherentzia eta aniztasuna orekatzea: Etengabeko harreman dialektikoan bizi dira bi kontzeptu hauek, eta erakunde edo taldeek bi aldagai hauen arteko etengabeko tentsioa orekatzeko eta kudeatzeko gaitasuna izan behar dute. Hau da, gaitasun, interes, nortasun, ikuspegi eta pentsatzeko hainbat modu izanik ere komunitatearen barnean, zatiketa ekiditeko gaitasuna izatea. Erakundeak gaitasunen arteko oreka mantendu behar dute maila desberdinetan - barnealdera zein kanpoaldera begirakoak, epe laburreko zein luzekoak...-. 
bezia, jarrera eta motibazio desberdinen multzoa. Sistemak edo gizarteak bere osotasunean daukan gaitasun gisa ere uler dezakegu gaitasun kolektiboa. Hau da, sistema batek balio publikoa sortzeko duen trebetasun orokorra edo gizarte batek etorkizuna zehaztu eta garatzeko daukan ahalmena. Balio publikoaren sorrera hau ordea, ezin da gaitasun kolektiboetara mugatu, izan ere, gaitasun indibidual eta kolektiboen arteko nahasketa batetik sortu behar da.

Balio publikoa sortzera bidean, hurrengo gaitasun kolektiboak proposatzen dituzte Baser eta Morganek (2008).

\subsection{Gaitasun zentral eta kolektiboak eta Ekonomia Sozial eta Solidarioa}

Ekonomia Sozial eta Solidarioak, proposatzen dugun garapen ereduarekin bat egiten du, eta horregatik, uste dugu ikuspegi ekonomiko honen praxiak Tokiko Giza Garapenerako beharrezkoak diren gaitasunak sustatzen laguntzen duela. Horregatik, ikuspegi ekonomiko honek gaitasun zentral eta kolektibo bakoitzari egin diezaiokeen ekarpena edo bulkada aztertzen saiatu gara REAS sareak eskaintzen digun Ekonomia Solidarioaren Gutuneko printzipioak ${ }^{5}$ oinarri hartuz (Guridi eta Perez de Mendiguren, 2014).

Hasteko, gaitasun zentralen eta Ekonomia Solidarioko printzipioen arteko harremana aztertzeari ekin diogu. Aipatzekoa da, bere egokitasunagatik Robeyns-en gaitasun zentralen zerrenda hartu badugu analisi enpirikorako euskarri bezala ere, bere ikuspegi orokor edo globalagatik interesgarria iruditu zaigula hipotesi teorikoa lantzeko, Robeynsenek bere zerrenda osatzeko euskarri gisa hartu zuen Nussbaumen (2002) hamar gaitasun zentralen zerrenda $a^{6}$ hartzea aztergai.

Nussbaumek hamar gaitasunetatik bi nabarmentzen ditu: arrazoi praktikoa eta afiliazioa (Nussbaum, 2008). Bi gaitasun hauek, beste guztiak bere baitan hartzen dituzte. Afiliazioak, beste pertsona batzuekin bizitzeko - berdintasun eta duintasun tratu bat oinarri izanez - gaitasuna adierazten du. Beste norbanakoen kezkak edota arazoak ulertu, bere lekuan jarri eta beraiengatik kezkatzeko gaitasuna. Pertsona duin gisa errespetuz tratatua izan eta diskriminazio oro — arraza, sexu, sexu orientazio, erlijio, et-

5 REASen ekonomia solidarioaren gutuneko sei printzipioak: a) Ekitate printzipioa; b) Lanaren printzipioa; c) Ingurumen-iraunkortasunaren printzipioa; d) Lankidetzaren printzipioa; e) «Irabazi asmorik gabeko» izatearen printzipioa; f) Inguruarekiko errespetuaren printzipioa.

${ }^{6}$ Gaitasun zentralen zerrenda: 1) Bizitza ; 2) Osasuna; 3) Osotasun fisikoa; 4) Zentzumena, imajinazioa eta pentsamendua; 5) Emozioak; 6) Arrazonamendu praktikoa; 7) Afiliazioa; 8) Beste espezieak; 9) Jolasa; 10) Ingurugiroaren gaineko kontrola (politikoa eta materiala) (Nussbaum, 2002). 
nia edota jatorria - gainditzeko zorua eskaintzen du honek. Arrazoi praktikoak ordea, ongiaren ideia egoki bat izan eta bizitzaren planifikazioaren gaineko hausnarketa kritiko bat egiteko gaitasuna aipatzen du.

Ekonomia Sozial eta Solidarioaren logika orokorrak —aktibitate ekonomikoaren helburua irabazien maximizazioa izatetik, pertsonen eta kolektiboaren bizi kalitatea izatera - eta hainbat printzipiok, zuzenean bi gaitasun zentral hauek indartzen laguntzeko oinarriak zehazten dituzte. Ekitate printzipioak, norbanako guztiek duintasun bera dutela dio, eta denak dutela menpekotasun harreman baten azpian ez egoteko eskubidea beren egoera soziala, generoa, adina, etnia, jatorria, gaitasuna eta abar edozein izanik ere. Horrez gain, gaitasun hauei ekarpena egiten dieten beste hainbat kontzeptu ere - elkarrenganako aitortza, aukera berdintasuna, parte hartze eskubidea, gardentasuna edota elkartasun antolatua - aipatzen dira ekitate printzipioaren baitan.

Ingurumenaren-iraunkortasuna eta inguruarekiko errespetua printzipioek, hirugarrenenganako — gizartea eta natura — errespetua dute oinarri, eta honek, berdintasunezko eta duintasunezko harremanak bultzatzeaz gain, ongiaren ideia egoki bat egiten lagun dezake. Bi printzipio hauek beraz, aurretik aipatutako gaitasun zentralez gain hurrengo gaitasunak indartzen ere lagun dezakete: bizitza, osasuna, osotasun fisikoa edota beste espezieak.

Azken honetan zentratuz, hau da, beste espezieekin —animaliekin, landareekin eta naturarekin - errespetuz eta tentuz bizitzeko gaitasuna (Nussbaum, 2008). Gaitasun hau, aurretik aipatutako ingurumen-iraunkortasunaren printzipioarekin zuzenean loturik dago (REAS, 2011). Ekonomia Sozial eta Solidarioaren ikuspegitik, jarduera ekonomiko oro naturarekin dago lotuta, era batera edo bestera, eta ondorioz, naturarekin harreman ona edukitzea aberastasun ekonomikoa defendatzea da (Coraggio, 2011). Ikuspegi ekologikoa bere egiten duen heinean gainera, beharrezkoa ikusten du jardunbide ekonomiko guztietan hirugarrenen gaineko eragina ebaluatzea (arrasto ekologikoa) eta eragina murrizteko — edo eraginik positiboa egiteko- borondatea izatea.

Aurrera jarraituz, lanaren printzipioa daukagu, Ekonomia Sozial eta Solidarioak lana jartzen du jardun ekonomikoaren eta giza jardueraren erdigunean. Lanari, giza dimentsioa ematen zaio, faktore produktibo huts bezala hartu beharren, norbanako bakoitzak gizartean integratzeko eta gaitasunaren garapenerako beharrezko duen faktore gisa hartzen da. Lanaren bitartez, norbanako bakoitzaren gaitasunak gizartearen zerbitzura jartzen dira, edozein motatako lan jarduera delarik ere — jardun produktiboa ordaindua, erreproduktibo (etxeko lana eta zaintza) ez ordaindua edota lan boluntarioa-. Lanaren dimentsio politikoari dagokionez, jardun ekonomikoaren gaineko erabaki politiko guztiak - ekoizpen baliabideen jabetzan eta erabakietan parte hartzeko eskubidea, laneko eta gizarte-elkarriz- 
ketarako oinarrizko eskubidea, komunitatea asetzeko produzitu beharrekoa planifikatzeko parte hartze eskubidea etab.- hartzen dira modu demokratiko eta parte hartzailean Ekonomia Sozial eta Solidarioko entitateetan. Dimentsio ekonomikoan, pertsonen premia ekonomikoak asetzeko lan baldintza duinak eta kalitatezko enplegua defendatzen ditu. Oinarrizko beharrizanak aseak izateak gaitasunak garatzeko abiapuntua eskainiko digu azken honek.

Lanaren printzipioak, Ingurunenaren gaineko kontrola izatearen gaitasuna indartzeko ahalmena duela esan dezakegu. Nussbaumek gaitasun honen bi alderdi — politikoa eta materiala — bereizten ditu. Alde batetik, gai politikoen gaineko erabakiak hartzeko eskubidea, hau da, parte hartze politikorako eskubidea edukitzeko gaitasuna. Bestetik, ingurumenaren gaineko kontrol materiala dugu, jabetzak — lurra edota ondasuna - izateko gaitasuna edo eskubidea (Nussbaum,2008). Ekonomia Sozial eta Solidarioko entitateetan, bi alderdi hauek funtsezkoak dira. Ikuspegi honek, autokudeaketa ekonomikoa du sustraietan, eta parte hartzea, modu zabalago eta koherenteago batean ulertzen da. Parte hartze eskubidea edo ingurumenaren gaineko kontrola bizitzaren esparru guztietara — gizartea, kultura, ekonomia, politika, etab. - zabaltzea defendatu eta praktikara eramaten du.

Ildo beretik, aipatu beharra dago, korronte ekonomiko honek ekonomia konbentzionalak merkatuan ezarrita duen lehiakortasunaren aurrean, lankidetza —norbanakoen artean, enpresaren barruan zein kanpoko agente pribatu eta publikoekin eta gizartean oro har- duela joko-arau (REAS,2011). Ekonomia Sozial eta Solidarioaren garapena, etika parte hartzaile eta demokratikoan oinarritu behar dela defendatzen dute, eta horretarako, lankidetzaren kultura sustatzen du. Gainera, aurretik esan bezala, lankidetza prozesu hauek eremu guztietara - herri, eskualde, autonomi erkidego, estatu eta mundu- zabaltzea bilatzen du. Lankidetzaren printzipioa, gaitasunen ikuspegiaren bilakaeran azaltzen den dimentsio kolektiboaren —ongizatearen dimentsio kolektiboa — beharrarekin bat dator.

Gaitasun kolektiboetara jauzi eginez, Baser eta Morganek (2008) proposatutako zerrendan zentrala konpromisoa eta erakarpena gaitasun kolektiboa da. Gaitasun honi esker lortuko dugu espazioak sortu, jabetza eduki, erabakigarritasuna izan eta nortasun kolektibo indartsua lortzeko trebetasuna. Ekonomia Sozial eta Solidarioak guztiz bat egiten du gaitasun kolektibo honek azaltzen duenarekin, izan ere, konpromisoa eta erakarpena etengabe bilatzen eta sustatzen den zerbait da. Ikuspegi ekonomiko honek, entitate edo erakundeetan parte hartzea eta beraien parte izatea bultzatzen du (REAS, 2011), eta behin kide izanda, informatuta egoteko eta parte hartzeko — jabetzan eta erabakiguneetan — eskubidea edukitzea defendatzen du. Gainera, proiektu komun baten parte izan, eta proiektu hori modu demokratiko eta parte hartzailean aurrera eramateak, nortasun ko- 
lektiboa sortzen du. Eguneroko lanerako estimulu gehiago dituzte, modu kolektiboan pentsatzen dute, informatuago daude... eta honi esker erakundearen jardueraren gainean konpromiso hartzeko eta parte hartzeko gaitasuna sustatzen dute. Horregatik esan dezakegu, Ekonomia Sozial eta Solidarioko entitate eta sareen funtzionatzeko eta antolatzeko moduak de facto indartzen duela gaitasun kolektibo hau. Paradigma ekonomiko honi esker, nortasun kolektibo ahaldunduago bat sortzen da eta kolektiboaren garapenaren bidean, zeregin logistikoak betetzea eta bere jarduera garatzea errazagoa izango da entitatearentzat (Baser eta Morgan, 2008).

Lanaren printzipioa eta lankidetza printzipioa hurrengo bi gaitasun kolektiboekin ere zuzenean lotuak daude: harremanak edukitzea eta laguntzak eta baliabideak lortzea eta egokitzea eta berritzea (Baser eta Morgan, 2008). Ekonomia Sozial eta Solidarioko enpresa bat, ekonomia konbentzionaleko beste enpresa edo agente desberdinekin harremanetan egoteak, gaur eguneko testuinguru aldakor eta konplexuetan bizirik irauteko eta garatzeko beharrezkoak diren ideia berri, laguntza edota baliabideak errazago lortzen laguntzen du. Etengabeko egokitze eta berritze prozesu batean aurrera egiteko gaitasuna izan beharko dut, eta berau sustatzeko eta indartzeko ahaleginak egin. Hala ere, tentuz ibili beharra dago, izan ere, merkatu kapitalistako logikak barneratzearen joera - merkatuko isomorfismoa - beti egongo da ekonomia konbentzionalean jarduten den heinean, ondorioz, joera hau saihesteko mekanismoak diseinatu beharko dira etengabe (Lanki, 2004).

\section{Kasuko azterketa: Agencia de Desenvolupament del Bergueda}

\subsection{Azalpen metodologikoa}

Esan bezala, artikulu honetan Agència de Desenvolupament del Bergue$d a$-ren kasuko azterketaren emaitzen azterketan zentratuko gara. Analisi enpirikoa gauzatzeko erabilitako metodologia bitan banatu da: Analisi objektiboa eta analisi subjektiboa. Analisi objektiboan, agentziek eskainitako informazioaren bitartez, esperientzia bakoitzaren hurrengo informazioa jaso da: aurkezpena, jatorria eta bilakaera; Ekonomia Sozial eta Solidarioko programa edo egitasmoen zerrenda; ezaugarritze taula (agentzien antolaketa eredua eta garapen estrategia ezagutzeko ikerketa honetarako prestatutako taula). Artikulu honetan, analisi objektiboaren laburpen azkar baino ez dugu egingo eta analisi subjektiboaren emaitzei emango diegu zentralitatea. Analisi subjektiborako elkarrizketa fitxa bat erabili da eta hiru subjektu edo agente desberdinei egin zaie elkarrizketa.

Elkarrizketa fitxaren diseinuari dagokionez, hiru zatitan banatu da fitxa. Lehen atalean, AMIA (Aukera, Mehatxu, Indargune eta Ahulezi) me- 
todologia erabili da, helburua, Tokiko Garapen Agentzietatik garatu diren Ekonomia Sozial eta Solidarioko egitasmoek dituzten aukera, mehatxu, indargune eta ahuleziak ezagutzea izanik. Bigarren atalean, marko teorikoan aurkeztutako gaitasun zentral eta kolektiboak zerrendatu dira eta balorazio-eskala (1: ez du batere indartzen; 5: guztiz indartzen du) baten bitartez agentziatik bultzatutako programa edo egitasmoek eta Ekonomia Sozial eta Solidarioak, oro har, gaitasun bakoitza sustatzeko duen ahalmena edo gaitasuna neurtzea bilatu da. Azkenik, galdera orokor batzuk jarri dira. Galdera hauen helburua agente ezberdinek Tokiko Giza Garapenaren eta Ekonomia Sozial eta Solidarioaren duten ezagutza eta iritzia ezagutzea izanik.

Elkarrizketatu diren hiru subjektuak hurrengoak izan dira: a) Agentzian Ekonomia Sozial eta Solidarioaren saila edo lan lerroa daraman arduraduna; b) Ekonomia Sozial eta Solidarioko programaren baten bitartez Ekonomia Sozial eta Solidarioko entitate bat sortu eta enpresa martxan duen talde bat; d) Agentziako Ekonomia Sozial eta Solidarioko programa baten bitartez Ekonomia Sozial eta Solidarioko entitate bat sortu berri edo sortzera bidean dagoen talde bat. Hiru elkarrizketa fitxen emaitzak analizatuko ditugu beraz kasuko azterketa honetan.

Kasuko azterketan beraz, Agència de Desenvolupament del Bergueda-ren eta eskualdearen gaineko kokapen orokor bat egin eta analisi subjektiboaren, elkarrizketa fitxaren, emaitzak aztertuko dira. Era horretara, egindako planteamendu teorikoaren eta hipotesi nagusiaren - Tokiko Garapen Agentziak eta Ekonomia Sozial eta Solidarioa, Tokiko Giza Garapena sustatzeko tresna eta euskarri baliagarriak direla- berrespen enpirikoa egitea bilatzen dugu.

\subsection{Analisi subjektiboaren emaitzak}

2013an Berguedako eskualdeko iniziatiba publiko eta pribatutik sortutako Agència de Desenvolupament del Bergueda da aztergai dugun esperientzia. Instituzio publikoari dagokionez, Consell Comarcal-ak agentzia sortzea eta tokiko garapenarekin erlazionatutako funtzioak bertan esleitzea erabaki zuen eta hori izan da agentziaren ernamuina.

Bergueda eskualdea, Kataluniako Bartzelona probintzian kokatzen da, 31 udalerri ditu, hiriburua Berga da eta agentziaren egoitza bertan kokatzen da. Eskualdeko ekonomia historikoki meatzaritza eta ehungintzatiko enpresa handiek osatu dute. Hau da, garapen exogenoa izan du eskualdeak, kanpoko enpresa trasnazionalak izan dira eskualdeko baliabideak ustiatu dituztenak. 80. eta 90. hamarkadetan enpresa trasnazional hauek alde egin zuten eta eskualdea oso egoera tamalgarrian gelditu zen. Kapital handien ihes honek langabezia handia sortzeaz gain, ehun enpresarial gabe utzi 
zuen Bergueda. Ondorioz, jendeak eskualdetik kanpo (Bartzelonan) bilatu behar izan du lana eta ehun enpresarial oso bat dute eratzeko.

Eskualde mailako agentzia honek, Berguedako norbanakoen eta gizartearen garapenean laguntzea du misiotzat. Enplegua sortzeko eta ekonomia eta turismoa sustatzeko tresna gisa hasi zen, baina pixkanaka badoa garapenaren esparru anitzagoetan eragiten. Garapen hau, beti ere, beharrezkoak diren aliantza estrategiko , kolaborazio -entitate eta agente ezberdinekin - eta ekinbideak martxan jartzeko hautua eginez. Gainera, tresna honek, eraldaketa sozial jasangarria eta norbanakoentzat eta ehun produktiboarentzat aukerak sortzea du helburu. Azken finean, Tokiko Garapen Agentzia honek, eskualdearen lehiakortasuna eta kohesio soziekonomikoa bultzatuko duen erreferentzia marka edo erakundea izan nahi du, horrela tokiko agenteen jarduna eta ekosistema indartuz.

Ekonomi Sozial eta Solidarioaren lan lerroa estrategikotzat dute agentzia honetan eta hurrengo dokumentuan azaltzen dute lan lerroaren gaineko informazioa: "Cap a la vertebració d'una caixa d'eines integral d'economia cooperativa, social i solidària; Pla de treball 2015-2016». Dokumentu honetan, ekonomia kooperatibo, sozial eta solidariorako erreminta kutxa integral bat sortzera bidean, 2015-2016 urteetarako lan egitasmoa azaltzen da.

Hurrengo lan egitasmoak daude martxan dagoeneko lan lerro honen baitan: 1) Ekonomia kooperatiboaren sustapena eta hedapena; 2) Ekintzailetasun kooperatiboan oinarritutako iniziatibei erraztasunak eta tresnak eman; 3) Kooperazioaren eta enpresa kooperatiboen akzio unitatearen sustapena; 4) Kooperatiba berrien sorrera sustatu sektore estrategikoetan: agroalimentarioa eta pertsonenganako arreta; 5) Ekonomia Sozial eta Solidarioaren dinamizazio plana eta zabalpena; 6) Ekonomia Sozialeko tresnen sustapena eta sentsibilizazioa; 7) Ondasun publikoen eta kontsumo kolaboratiboaren sustapena; 8) Ordainketa sozialeko sistema (moneta soziala).

Behin, eskualdearen eta agentziaren gaineko inguruabarrak ezagututa, analisi subjektiboaren emaitzak aztertzera pasako gara. Elkarrizketa fitxa eskuan, hiru subjektu edo agenteak (E1, E2 eta E3) ${ }^{7}$ elkarrizketatu ditugu.

7 E1: 2013tik agentziako ekonomia sozialeko programaz arduratzen den teknikoa da; E2: Metalaren eraldaketan aritzen den kooperatiba da eta 2014an sortu zen agentziaren laguntzari esker. Sektore berean aritzen zen erantzukizun mugatuko enpresa bateko langileak ziren kooperatiba osatzen duten 4 kideak, nagusiak 2013an enpresa itxi zuen arte; E3: 1992an bertan behera utzitako kolonia zahar batean hiruzpalau lagunek materializatutako proiektua da. Etengabeko eraldaketan bizi den proiektua da, artea eta kultura sortu - fabrika kuturula - eta elkarbanatzeko espazioa da eta jatetxe bezala ere funtzionatzen du. Elkarrizketa egin aurretik, elkarte kultural baten izaera juridikoa zuten, hala ere, agentziaren laguntzarekin kooperatiba bat sortu berri dute aktibitate guztiak kudeatzeko. 
Garrantzitsua iruditu zaigu, elkarrizketak egiterako orduan ikuspegi integral bat mantentzea eta agente ezberdinen pertzepzioa jasotzea Tokiko Garapen Agentzien - tresna instituzional gisa- eta Ekonomia Sozial eta Solidarioren —euskarri ekonomikoa — gaitasuna neurtzeko Tokiko Giza Garapena bultzatzeko orduan. Aipatu beharra dago, agentziako teknikariaz gain elkarrizketatutako agenteak, ekintzailetza kooperatiboan oinarritutako iniziatibei erraztasunak eta tresnak emateko zerbitzuen hartzaile izan direla.

\section{a) AMIA emaitzen azterketa}

Analisi subjektiboaren emaitzak analizatzen hasteko, agentziatik sustatutako Ekonomia Sozial eta Solidarioko programa eta zerbitzuen gaineko AMIAren emaitzak aurkezten hasiko gara.

Aipatu bezala, historikoki eskualdeak jasan duen garapen exogenoaren ondorioz, eskualdea ehun enpresarial oso ahularekin eta langabezi tasa altuekin gelditu da. Garapen sozioekonomikoaren ikuspegitik, egitura ekonomikoen falta hau desabantaila izugarria izan arren, aukera ugari sortzen ditu garapen endogenoaren logikan garatzeko. E1en ustez, ehun enpresarialaren egoerak, ehun kooperatibo indartsu bat sortzeko aukera ematen du eta egun duten aukera politikoa ere aprobetxatu beharra dagoela iruditzen zaio. Izan ere, egun lurraldean boterean daudenak Ekonomia Sozial eta Solidarioaren diskurtsoarekin bat egiten dute eta horrek asko erraztu dezake bidea. E2ren hitzetan, agentziatik eskaintzen duten laguntzak E1ek aipatutako ehun kooperatibo berria sortzen lagun dezake. Beraien kasuan, kooperatiba sortzeko jasotako aholkularitza teknikoari eta finantzazio iturriak aurkitzeko (Coop57 bitartez lortu zuten finantzazioa) laguntzari esker eratu zuten kooperatiba. Agentziaren Ekonomia Sozial eta Solidarioko aholkularitza zerbitzuek eman zien aukera hau. E3ren ustetan ordea, agentziatik garatutako programek ez dute inongo aukerarik sortu beraientzat. Bakoitzak bilatzen dituela bere aukerak dio.

Mehatxuei dagokienez, E1ek bi nabarmentzen ditu: alde batetik, gobernanatza mailen arteko balditzapena, izan ere, agentzia Consell Comarcalaren menpean dago eta bertatik baldintza daitezke agentziaren lan egitasmo ezberdinak. Bigarrena, ildo beretik doa eta diru laguntza publikoen gaineko menpekotasuna da. «Diru laguntzak proiektuka doaz eta laguntzarik ez badago ez dago finantzazio iturririk proiektuentzat. Ez dago finantzazio iturri propiorik» dio. Gehitzen du, proiektu bat promozionatzen denean, beti ez dela diru laguntza heltzen eta ondorioz proiektua ezerezean gelditzen dela eta «kea saldu» duzunaren sentsazioa gelditzen dela. Gainera, burokrazia geldoa eta astuna dela ere gehitzen du. Azken mehatxu bezala, eskualdeko arazo demografikoa nabarmentzen du. Izan ere, biztanleria oso zaharkitua du eskualdeak eta gazteen exodoa hirira — Bartzelonara kasu 
honetan - oso kezkagarria dela uste du. Hala ere, arazo demografiko hau mehatxu eta aukera da aldi berean. Giza kapital urria gelditzen da Ekonomia Sozial eta Solidarioko proiektuak martxan jartzeko, baina aldi berean 3.adineko pertsonei zuzendutako zaintza zerbitzuen beharra nabaria -enplegu aukera - da, horregatik sustatzen da sektore estrategiko (Silver Economy) bezala.

E2k ez du mehatxurik identifikatzen. E3k ordea, mehatxu bakarra aipatzen du: kooperatiben estigmatizazioa. Bere ustez, kooperatibak gehiegi estigmatizatuta daude. «Ez da bandera kontu bat, kooperatiba bat izan edo sozietate anonimo bat izan, ez da izaera juridikoa garrantzitsuena» dio.

Indarguneekin sartuz, E1ek Ekonomia Sozial eta Solidarioko programak garatzeko orduan agentziako egituraren gaitasun tekniko eta profesionala nabarmentzen du. Eskualdeko udalerri guztiak daude agentziaren barne, lurraldetasun adostua — «ambito territorial consensuado»— dago eta errekurtso tekniko (azpiegiturak) eta humano (langile kualitifikatuak) onak ditu. Beste aldetik, teknikoaren ustez, lan handia egin da Ekonomia Sozial eta Solidarioaren sustapen eta sentsibilizazioan eta garatzen ari diren lan egitasmo estrategikoek potentzialitate handia dutela uste du. Egindako sentsibilizazio lanean nabarmentzekoa eta arrakasta gehien izan duena, Derrigorrezko Bigarren Hezkuntzan ematen duten Ekonomia Sozial eta Solidarioaren gaineko formazio praktikorako programa da. Ikasleek urte osoan zehar produktu edo zerbitzu bat diseinatu eta garatzen dute taldeka, formazio teorikoarekin uztartuz eta ikasturte bukaeran antolatzen den azoka batean beraien produktu eta zerbitzuak plazaratzen dituzte. E2ko langileek ere, egitasmo honek izugarrizko potentzialitatea duela uste dute eta indargune bezala jartzen dute, izan ere, ikasleak izango baitira eskualdearen etorkizuneko motor. Kooperatiba honetako kideen hitzetan, agentziatik gidatutako programen beste indargune nagusietako bat, porrot egindako enpresak langileen eskutik berreskuratzeko jarritako ahalegina eta laguntza da. Beraientzat ezinbestekoa izan da laguntza hau. E3k ildo beretik, kooperatiba sortzeko izandako laguntza profesionala eta «inplikazio handia» nabarmentzen ditu.

E1ek azken indargune bezala, eskualdeko oinarri sozial asoziatuaren indarra aipatzen du. Eskualdeko konposizio demografikoaren arazo edo mehatxua hor egon arren, ehun asoziatu garrantzitsua du eskualdeak. 560 elkarte ditu gutxi gorabehera. Ehun sozial indartsu hau izugarrizko aberastasuna da eskualdearentzat eta proposatzen dugun garapen estrategia aurrera eramateko baldintzak nabarmen hobetzeaz gain, Ekonomia Sozial eta Solidarioan oinarritutako lan egitasmo anitzak aurrera eramateko aukera ematen du honek. Kontsumoaren ikuspegitik esaterako, garapen endogenoaren logikan eta merkatu sozialaren ideiarekin bat eginez, kontsumo kritikoa sustatu eta kontsumo kooperatibak sortzeko ehun sozial indartsua du eskualdeak. 
Azkenik elkarrizketetan ateratako ahuleziekin sartuko gara. E2k, eskualdearen garapen endogenoa sustatzeko espazio edo foro baten gabezia nabarmentzen du. Ekonomia Sozial eta Solidarioko enpresen sare bat —interkooperazio sarea - falta dela diote, baina ez egotearen arrazoi nagusia agian enpresa gutxi egotea dela diote. Hala ere, era honetako sare, espazio edo foro batek interkooperazioan oinarritutako harremanak sortzeko eta eskualdeko ekonomia indartzeko balio dezakeela uste dute. Honekin batera, garapen endogenoa sustatzeko gaitasun falta nabarmentzen dute. Administrazio publikoen aldetik, diru publikoa ez dela ekonomia lokala bultzatzeko erabili kritikatzen dute. Obra publikoen edota zerbitzu publikoen esleipenean kanpoko enpresak kontratatu dituztela salatu dute eta beraien kooperatibaren kasuan ere, eskualdeko bezero bat (pribatua) baino ez omen dute.

E1en ustetan, Ekonomia Sozial eta Solidarioko mugimendua indartzeko aukerak galdu izana ahulezi garrantzitsutzat jotzen du. Martxan jarri diren hainbat programa, coworking espazioa esaterako, ez dira lehentasunezko jarri eta ez da beraien potentzialitate osoa esplotatu. Honen arrazoietako bat, teknikariak aipatzen duen beste ahulezi bat izan daiteke, agentziaren kudeaketa eta antolaketa zaharkitua. Agentziaren sorrera oso berritzailea izan omen zen, baina funtzionatzeko modu nahiko ortodoxoa duela kritikatzen du. "Organigrama oso bertikala du agentziak, 26 langile eta 11 arduradun ditu» dio eta antolaketa eredu zaharkituak erreproduzitzen daudela uste du. Azken ahulezi bezala, programen inpaktua edo eragina eta inbertsio publikoaren erretornu soziala neurtzeko adierazleen falta aipatzen du.

b) Gaitasun zentral eta kolektiboak sustatzeko gaitasunaren neurketa

Analisi subjektiboaren bigarren atalean, Ekonomia Sozial eta Solidarioko programa edo egitasmoek eta ikuspegi ekonomikoak berak, gaitasun zentral eta kolektiboak sustatu edo indartzeko duen ahalmena neurtzea bilatu da.

E1en kasuan, Ekonomia Sozial eta Solidarioko proiektu eta entitateei emandako aholkularitza eta akonpainamenduaren ikuspegitik erantzun da fitxa. Gainontzeko elkarrizketatuek, zerbitzu hauen hartzaile bezala erantzun dute. Aipatu beharra dago, atal hau izan dela elkarrizketatuei erantzutea gehien kostatu zaien atala, izan ere, ez da erreza norbere gaitasun pertsonal eta kolektiboen bilakaera baloratu eta kuantifikatzea. Hala ere, honek ebidentzian jartzen du, Ekonomia Sozial eta Solidarioko entitateen baitan, eta gizartean oro har, ahalduntze pertsonal eta kolektiboak oraindik ez duela eduki beharko lukeen garrantzia. 
Gaitasun zentralei dagokionez, E1 eta E2k antzeko iritzia dutela esan dezakegu. E3k ordea, bestelako iritzia du. E1en ustetan bost dira gehienbat indartzen diren gaitasunak: osotasun eta segurtasun fisikoa izatekoa (3); sare sozialen baten parte izan eta suntengu soziala eman eta hartzekoa - harreman sozialak (4)—; ikasteko, ikasitako irakatsi eta jakintza sortzekoa -hezkuntza eta jakintza (6)-; denboraren erabileraren gaineko erabakitzeko ahalmena izatea (12); eta, errespetuz eta duintasunez tratua izateko eta tratatzeko gaitasuna - errespetua (13)—. E2ren ustetan ordea, harreman sozialak izateko gaitasuna (4) eta denboraren erabileraren gaineko erabakitzeko gaitasuna gutxi lantzen dira Ekonomia Sozial eta Solidarioaren bitartez eta ahalduntze politikoa (5) eta lan egin eta enplegua - lan ordaindua (enplegua) eta beste proiektuak (8) - izateko gaitasunak asko.

Hein handi batean, Ekonomia Sozial eta Solidarioak oinarrizko bizi baldintzak bermatzeko, gizartean harremantzeko eta norbanako guztiek bizitza duina izateko gaitasun zentralak indartzen laguntzen duela esan dezakegu. Aho betez esan ezin badugu ere, izan ere, zentralak diren beste hainbat gaitasun ez dira nahi beste sustatzen.

E1n ustetan, etxeko lanak eta zaintza lanak egiteko gaitasuna (7) ez dela indartzen dio, bere iritziz lagun dezake baina ezer gutxi egin da orain arte esparru honetan. E2ren ustetan ordea laguntzen du, asko ez bada ere. Beraien kooperatibaren kasuan esaterako, zaintzarako denbora hartzen usten da.

Hiru elkarrizketatuek bat egiten dute, lau gaitasunen bilakaeraren gaineko iritzian. Beraien ustetan, proposatzen dugun paradigma ekonomikoak hurrengo gaitasunak indartzeko ahalmen oso urria du: ingurune seguru eta egoki baten seguru bizi ahal izateko gaitasuna - etxebizitza eta ingurumena (9)—; mugikortasun askatasuna (10); aisialdi ekimenetan parte hartzeko gaitasuna (11); eta, erlijio bat aukeratu eta izateko edo ez izateko gaitasuna —erlijioa (14)—.

Nahiko agerian gelditzen da, lau gaitasun hauek indartzeko gaitasunik ez duela Ekonomia Sozial eta Solidarioak. 10. eta 11.en gaitasun zentralak ez sustatzearen arrazoia, era honetako entitateek izaten duten gehiegizko lan karga eta langileen dedikazio eta konpromiso maila altua izan daitezke, eurak baitira beraien lanaren nagusi. Bestalde, proiektuak territorioan sustraituak egoteak eta lanaren izaera mugagabeak iraupenari dagokionean, langileen mugikortasuna zaildu dezakeela esan dezakegu. Erlijioari dagokionez, ez dela sustatzen baloratzearen arrazoia, erlijioak entitate hauetan duen garrantzia hutsala izan daiteke. Hala ere, ezin dugu balorazio hau orokortu, izan ere, jatorri sozial-kristaua duten Ekonomia Sozial eta Solidarioko entitateetan bestelako garrantzia izan dezake erlijioak.

Hasieran esan bezala, E3k oso bestelako iritzia du, elkarrizketatuaren ustetan, errespetuz eta duintasunez tratatua izan eta tratatzeko gaitasuna da 
bereziki indartzen den bakarra, hurrengo lau gaitasunak - harreman sozialak (4), ahalduntze politikoa (5), hezkuntza eta jakintza (6) eta denboraren erabileraren gaineko erabakitze ahalmena (12) - pixkat indartzen direla uste du. Gainontzeko gaitasunak indartzerako orduan ordea, Ekonomia Sozial eta Solidarioak ez duela aparteko ahalmenik dio.

Beti ere desadostasunak kontuan hartuz, orokorrean Ekonomia Sozial eta Solidarioak, intentsitate berarekin ez bada ere, gaitasun zentralak indartzeko ahalmena duela baiezta dezakegu.

Gaitasun kolektiboei dagokienez, argi dagoena da prozesu kolektibo bat dela Ekonomia Sozial eta Solidarioak sustatzen duena eta dimentsio kolektiboak berebiziko garrantzia duela. Izan ere, gaitasun kolektibo guztiek jaso dute balorazio positiboa. Bereziki, funtzio logistikoak betetzea eta zerbitzu eta teknikak eskaintzea (2) eta egokitzea eta berritzea (4) izan dira elkarrizketatuen iritziz gehienbat potentzializatzen diren gaitasun kolektiboak. 2. gaitasun kolektiboari dagokionez, E1k dio ahalegin berezia egin dela gaitasun hau garatzeko eta zerbitzu eta laguntza asko bideratu direla horretara. E2k ere, esfortzu handia egin du gaitasun hau indartzen eta horri esker asko hobetu dute kooperatibaren funtzionamendua eta zerbitzuak emateko gaitasuna. Egokitu eta berritzeko gaitasunari dagokionez, E1k bere ikuspegitik, botere politikoaren aldaketei nahiz gobernantza mailen arteko baldintzapenei egokitzeko gaitasuna nabarmendu nahi izan du.

Konpromisoa eta erakarpen (1) gaitasunaz hitz egitean, bi kooperatiben kasuan asko indartzen dela nabarmendu da. E2k horrela azaldu digu: « konpromiso handia hartu dugu denok enpresa berreskuratzean». E1en ustetan ordea, Ekonomia Sozial eta Solidarioak, mugimendu bezala ez du gaitasun kolektibo hau sustatzeko ahalmenik eduki, izan ere, mugimenduaren inguruan jendea biltzeko gaitasuna ez da hobetu.

\section{d) Galdera orokorren emaitzen azterketa}

Analisi subjektiboaren irakurketarekin bukatzeko, elkarrizketa fitxako galdera orokorren atala aztertuko dugu. Hiru galdera orokor egin zaizkie elkarrizketatuei: 1) Ekonomia Sozial eta Solidarioak ahalduntze pertsonal eta kolektiboan eragiten duela uste duzue? Zergatik?; 2) Tokiko Garapen Agentziak Tokiko Giza Garapena sustatzeko tresna egokiak direla uste duzue?; 3) Garapen endogenoa eta gobernantza lokala beharrezkoak direla uste duzue territorioaren garapena eta ongizate pertsonal-kolektiboa sustatu eta indartzeko?

Lehen galderari erantzunez, E1 eta E2k argi dute paradigma ekonomiko honek ahalduntze pertsonal eta kolektiboan laguntzen duela. E2ren ustetan, ideia bat eduki eta garatzeko aukerak, erabakitzeko ahalmenak eta erabakietan eragiteko gaitasunak pertsona bezala hobetu eta ahalduntzen 
zaitu, beti ere, kolektiboa oinarri izanik. E3ren ustetan, ez du zertan, kooperatiben gehiegizko estigmatizazioak, ahalduntze prozesu faltsuak sor baititzake.

Tokiko Garapen Agentzian gaitasunaz galdetzean, hiru elkarrizketatuek garapen agentziak tresna erabilgarriak direla erantzun dute, baina guztiek gehitu dituzte ñabardura batzuk. E1k dio, ez dela tresnaren formatua garrantzia duena, bere edukia baino. Tresna egokia, eduki egokiak (funtzionamendua, programak, garapen eredua...) dituena izango dela uste du. E2 eta E3k, tresna erabilgarria dela azaldu dute, baina gauza asko daudela hobetzeko. Ezjakintasun handia dagoela agentziaren lanaren inguruan dio E2k eta herritarrengana heldu behar duela, hezkuntzaren esparruan egin diren lanketak eredu hartuz.

Azken galdera, garapen eta gobernantza ereduaren gainean galdetzean, hiruak izan dute zer esana. Guztiek dute oso argi garapen endogenoa beharrezkoa dela, E3ren ustez gainera modu naturalean ari da aurrera egiten, izan ere, eskualdeak garapen exogenoaren ondorio tamalgarriak bizi izan ditu eta oso presente dute hori. «Eskualdearen garapena endogenoa izango da edo ez da izango» dio E1K. Garapen endogenoa ordea, gobernantza lokal indartsu baten eskutik etorriko dela azaltzen dute. E2K, territorioko agenteek, instituzio publikoen laguntzarekin, bertako beharrak asetzeko jarduerak eraman behar dituztela aurrera defendatzen du, baina beti ez dela horrela izaten. Kritika bezala beraien esperientzia azaltzen du. Eskualde osoko zaborrontziak aldatu behar ziren eta territorioko instituzioek bertako enpresa bati - E2 kasuko- eman beharrean hornidura publikoko kontratua, kanpoko enpresa bati eman zioten. Adibide bat baino ez da, baina gobernantza lokalak garapen endogenoa sustatu nahi badu eredu izaten hasi behar dela nabarmendu dute. E1Ek, kritika hau onartu eta gobernantza lokalaren berrindartze bat eta goragoko gobernantza maialetara delegatutako eskumenak berrartzearen garrantzia gehitzen du. Soilik, era horretara lortuko omen da garapen endogeno jasangarri bat.

\section{Ondorio nagusiak}

Artikuluaren sarreran aipatu bezala ikerketaren hipotesi nagusia hiru zutaberen baitan garatu da eta esperientzia konkretu bat hartu da aztergai analisi enpirikorako, izenburuak ondo laburbiltzen duen bezala, "Tokiko Garapen Agentzien eta Ekonomia Sozial eta Solidarioaren gaitasuna Tokiko Giza Garapenaren bidean: Agència de Desenvolupament del Berguedaren esperientzia aztergai».

Maila teorikoan, egungo ekonomia eta garapen eredua zalantzan jarri eta hazkunde ekonomikotik haratago doan garapen eredu berritu baten 
- Tokiko Giza Garapena- beharra azaleratu eta bide horretan kontuan hartu beharreko gakoak zeintzuk diren nabarmendu ditugu. Tokiko Giza Garapenerako estrategia garatzeko bide horretan tokiko dimentsioaren - subsidiariotasun printzipioa eta garapen endogenoa- eta gaitasunen ikuspegiaren — giza garapena - garrantziaz hitz egin dugu.

Alde batetik, garapen estrategia garatzeko espazioa, tokikoa - territorioa - izan behar dela defendatu dugu, eta tokikoa esatean auzo, herri, hiri edo eskualdeko mailaz aritu gara. Afera honetan, gure inguruabarra kontuan hartuz eta subsidiariotasun printzipioa oinarri, Tokiko Garapen Agentziak proposatu ditugu garapen estrategia sustatzeko tresna instituzional gisa. Beste aldetik, Duboisek aipatutako garapen endogenoaren premisarekin bat eginez, tokian tokiko norbanako eta agenteak - ekonomikoak, sozialak, instituzionalak eta politikoak - izan beharko dira beraien territorioan ongizate pertsonal eta kolektiboa lortzen lagunduko dien garapen eredua eta garapen estrategia definituko dutenak eta Tokiko Garapen Agentziek fazilitazio lana egin beharko dute. Hala ere, horretarako gobernantza lokalaren berrindartze bat ezinbestekoa dela ondorioztatu dugu. Hau da, boterearen deszentralizazio bat ematea eta goragoko gobernantza mailetara transferitu diren eskumen erregulatzaileak berrartzea. E1ek ere hala dio: "Garapen endogeno jasangarri bat izateko beharrezkoa izango da gobernantza lokalaren gaitasuna indartzea eta goragoko organoetara delegatutako eskumenak berrartzea».

Bestalde, gaitasunen ikuspegiaren bilakaera aztertuz ikusi dugu, edozein garapen eredutan giza garapena ezinbestekoa dela, gizakiaren ongizatea eta oinarrizko justizia soziala lortu nahi bada. Tokiko Garapenaren eredu konbentzionalak, ez du giza garapena kontuan hartzen edo ez dio zentralitate nahikoa ematen, hazkunde ekonomiko hutsarekin gizartean ongizatea lortuko dela defendatzen du eta oinarri teoriko nahiko dugu hori horrela ez dela baieztatzeko. Tokiko Giza Garapenaren barnean hazkunde ekonomikoa beharko dugu bai, baina garapenak ikuspegi integralago — soziala, ekonomikoa, kulturala, politikoa...- bat izan behar du eta esparru guztietatik eragin.

Gaitasunen ikuspegiarekin jarraituz, aipatu beharra dugu oso garrantzitsua izan dela gaitasunen garapena ongizatearen dimentsio kolektiboa kontuan hartuz aztertzea. Izan ere, gaitasunek, norbanako bakoitzari berak bizi nahi duen bizitza askatasun osoz bizitzeko trebetasuna ematen baldin badio, non hasi eta non bukatzen dira bataren eta bestearen askatasunak. Gizakia izaki soziala den heinean beti egongo da hirugarrenekin erlazionatu, ondorioz beharrezkoa da ongizatearen dimentsio kolektiboa ere kontuan hartzea. Gizarteak, kolektibo edo sistema bezala, balio publikoa sortzeko gaitasuna izan behar du garapenaren bidean, horregatik, gaitasun pertsonalak lortzeaz gaindi, gaitasun kolektiboak ere garatu behar dira. Ongizatea 
lortzeko prozesu pertsonal zein kolektibo bat garatu behar dela uste dugu, horregatik ezinbesteko ikusi dugu analisirako gaitasun pertsonalak eta gaitasun kolektiboak aztergai hartzea.

Behin garapen ereduaren gaineko ondorio nagusiak azalduta, Ekonomia Sozial eta Solidarioak Tokiko Giza Garapenean joka dezakeen papera aztertzera pasa gara. Atera dugun lehen ondorioa, eredu sozioekonomikoaren paradigma aldaketa baten beharra izan da, Tokiko Giza Garapen estrategia eraginkor bat gauzatu nahi bada. Ekonomia konbentzionalak ekonomiaren antolaketarako ezarritako oinarrizko printzipio eta arauekin hautsi eta Ekonomia Sozial eta Solidarioa izan beharko litzateke etorkizuneko jardun edo prozesu ekonomikoen euskarri. Gaitasun pertsonal eta kolektiboak ikuspegi ekonomiko honen printzipio eta baloreekin alderatu ditugu eta argi ikusi dugu, Ekonomia Sozial eta Solidarioak gaitasun oro bermatzeko eta garatzeko ahalmen esanguratsua duela. Pertsona jartzen du jardun ekonomikoaren zentroan, errentagarritasun ekonomikoa bitarteko eta gizakien beharrak modu kolektiboan asetzea bilatzen du. Ongizatearen dimentsio kolektiboa barnebiltzen du korronte ekonomiko honek eta Tokiko Giza Garapenaren logikarekin guztiz bat datorrela argi esan genezake. Horregatik, oso garrantzitsua iruditzen zaigu Ekonomia Sozial eta Solidarioa izatea, Tokiko Giza Garapenean, aktibitate edota prozesu ekonomiko ororen euskarri. Ikuspegi ekonomiko hau etorkizuneko gizarte justuago baten enbrioi, eskola, subjektu sortzaile, laborategi eta eredu izan behar litzateke.

Datu enpirikoekin ere baieztatu ahal izan dugu hipotesi nagusi hau. Desadostasunak desadostasun, hiru elkarrizketatuek baloratu dute, Ekonomia Sozial eta Solidarioa euskarri ekonomikotzat hartzeak gaitasun pertsonal eta kolektiboen indartzen laguntzen duela eta galdera orokorrei erantzunez ere, paradigma ekonomiko honek ahalduntze pertsonal eta kolektiboan laguntzen duela nabarmendu dute. Ildo beretik, Ekonomia Sozial eta Solidarioa euskarritzat duten Tokiko Garapen Agentziak tokiko garapen estrategiak sustatzeko tresna egokiak direla baieztatu dute. Hala ere, tresnaren praxia dela garrantzitsuena nabarmendu da eta beti dagoela zer hobetu.

Egindako berrikuspen bibliografikoari eta kasuko azterketari esker, gure hipotesi nagusia baieztatu eta hurrengo hiru ondorio nagusiak ateraez itxiko dugu artikulua. Batetik, Tokiko Giza Garapena izan behar dela jarraitu beharreko garapen eredua; bestetik, Ekonomia Sozial eta Solidarioa izan behar dela garapen eredu honen euskarri izango den eredu ekonomikoa; eta bukatzeko, Ekonomia Sozial eta Solidarioko egitasmoak sustatzen dituzten Tokiko Garapen Agentziak tresna egokiak izan daitezkeela Tokiko Giza Garapeneko estrategiak bultzatzeko. 


\section{Bibliografia}

BASER, Heather; MORGAN, Peter (2008): Capacity, Change and Performance. Study Report. European Centre for Development Policy Management. Discussion Paper 59 B.

DUBOIS, Alfonso (2008): El debate sobre el enfoque de las capacidades: las capacidades colectivas. Hegoa Institutua.

DUBOIS, Alfonso (2014): Tokiko Giza Garapenaren marko teorikoa eta metodologikoa. Hegoa Institutua.

CORAGGIO, José Luis (2011): Economía social y solidaria. El trabajo antes que el capital. Alberto Acosta eta Esperanza Martínez (Argitaratzaileak). FLACSO/ Abya Yala. Quito.

GURIDI, Luis eta PEREZ, Juan Carlos (2014): Tokiko Giza Garapenaren dimentsio ekonomikoa. Hegoa Institutua.

JUBETO, Yolanda eta LARRAÑAGA, Mertxe (2013) : El DHL desde la equidad de género: un proceso de construcción. Hegoa Institutua

JUBETO, Yolanda (2011): Auzolana eta herrigintzaren inguruko begirada ekonomikoa. Udako Euskal Unibertsitatea (UEU). Eibar.

KAZEPOV, Yuri (2010): Rescaling Social Policies towards Multilevel Gobernance in Europe. European Centre Vienna.

LANKI (2004): Autogestión y globalidad. Situar la autogestión económica en el mundo actual. Cuadernos de Lanki 1.

NUSSBAUM, Martha (2002): Las mujeres y el desarrollo humano. El enfoque de capacidades. Herder.

NUSSBAUM, Martha (2003): Capabilities as Fundamental Entitlements: Sen and Social Justice. Feminist Economics, 9 (2-3).

NUSSBAUM, Martha (2012): Crear capacidades. Propuesta para el desarrollo bumano. Paidos, Barcelona.

REAS , Sareen Sarea (2011): Ekonomia Solidarioko Printzipioen Gutuna.

SEN, Amartya (1990): «Gender and comparative conflict.»I. Tinker (ed.) Persistent inequialities. Womern and world development. Oxford: Oxford University Press.

SEN, Amartya (2000); Desarrollo y libertad. Editorial planeta. 